\title{
Prevalence and determinants of protein energy malnutrition among under five children in slums of Kannauj district
}

\author{
Tanu Midha ${ }^{1, *}$, Seema Nigam², DS Martolia ${ }^{3}$, Samarjeet Kaur ${ }^{4}$ \\ ${ }^{\mathbf{1}}$ Associate Professor, ${ }^{\mathbf{2}, 3}$ Professor and Head, ${ }^{\mathbf{4}}$ Assistant Professor, Dept. of Community Medicine, ${ }^{\mathbf{1 , 3}}$ Government Medical College, \\ Kannauj, Uttar Pradesh, ${ }^{2,4}$ Ganesh Shankar Vidyarthi Memorial, Medical College, Kanpur, Uttar Pradesh, India \\ *Corresponding Author: Tanu Midha \\ Email: tanumidha2001@gmail.com
}

\begin{abstract}
Introduction: Protein Energy Malnutrition (PEM) in children is a leading public health problem in developing countries like India and is a direct or indirect cause of most of infant and child morbidity and mortality.

Objective: To study the prevalence and determinants of protein energy malnutrition among under five children of Kannauj district.

Materials and Methods: The present study was a cross-sectional study conducted among children in the age group 0-60 months in the slums of Kannauj district. The statistical tools used for analysis were percentages, Pearson's Chi-square test and multiple logistic regression.

Results: The prevalence of PEM in the study population was found to be 59.1\%. The study revealed a significant association of age $(\mathrm{OR}=0.438)$, timing initiation of breast feeding $(\mathrm{OR}=0.682)$, colostrum feeding $(\mathrm{OR}=0.364)$, practice of breast feeding $(\mathrm{OR}=3.611)$ and initiation of complementary feeding at 6 months $(\mathrm{OR}=2.651)$ were significantly associated with PEM.

Conclusion: The present study emphasizes the need to correct behavioural factors like breast feeding practices among Indian mothers to bring down the problem of PEM in under five children.
\end{abstract}

Keywords: PEM, Under five children, Malnutrition, Determinants.

\section{Introduction}

India has the largest number of children in the world. UNICEF has reported that in 2011, the total number of live births in the country was around 27 million, which was approximately $20 \%$ of the total number of live births globally. ${ }^{1}$ Early childhood, that is the first five years are the most crucial years of life, $\mathrm{s}$ this is the time when the foundation is laid for both physical and mental growth and development.

Under-five children comprise around $13 \%$ of the Indian population. These children are most vulnerable to deficiencies or malnutrition. Childhood malnutrition is a major public health problem in developing countries like India and is the leading cause of infant and child morbidity and mortality. Childhood morbidity and mortality is a sensitive indicator of a country's socio economic development. Protein energy malnutrition (PEM), which is manifested as decrease in weight for age or height for age or weight for height, is the most widely prevalent form of malnutrition among under-five children. According to UNICEF, worldwide, more than one third of under-five deaths are a consequence of under nutrition. India is among the countries where childhood malnutrition/under nutrition is most common.

As per NFHS-3 (2005-06), in India, $48 \%$ of the children below five years are stunted, $42.5 \%$ are underweight and $19.8 \%$ are wasted. India has 3 out of every 10 stunted children in the world. ${ }^{2}$ Around 46\% stunted, 9\% wasted and $26 \%$ underweight children are living in slums. Thus, around one third of the world's children who are stunted, live in India. Also, there are wide variations in nutritional status of children across India. In 2008, the under-five mortality rate in Uttar Pradesh was 91 per 1,000 live births and the prevalence of stunting, wasting and underweight in children under 5 years was $56.8 \%, 14.8 \%$ and $42.4 \%$ respectively. Another study from Uttar Pradesh revealed a prevalence PEM of 54.8\% in Azamgarh district. ${ }^{3}$

UNICEF report of the year 2014 revealed that in India, early initiation of breast feeding (within 1hour) was done by only $41 \%$ mothers. ${ }^{4}$ Only $46 \%$ children were exclusively breast fed. ${ }^{5}$ Solid, semi-solid and soft foods were initiated by $6-8$ months by only $56 \%$ mothers. Around $77 \%$ children were breast fed up to the age of 2 years.

Given the high prevalence of protein energy malnutrition in India and the faulty feeding practices, this study was conducted to study the prevalence and determinants of protein energy malnutrition in under five children of Kannauj district.

\section{Material and Methods}

The present study was a cross-sectional study conducted among children in the age group 0-60 months in the slums of Kannauj district. The minimum sample size was calculated taking the prevalence of underweight in children under five years as $42.4 \%$ (NFHS-III, Uttar Pradesh, 2005- 2006) using the following formula: Minimum sample size $(n)=Z^{2} P Q / d^{2}$ where, $Z=$ Standard normal variate having value 1.96 at $95 \%$ confidence interval.

$\mathrm{P}=$ Prevalence \% (42.4) $\mathrm{Q}=(100-\mathrm{P}) \%(57.6) \mathrm{d}=$ Margin of error (5)

Thus $\mathrm{n}$ was calculated to be 390 . There were only 10 slums in district kannauj therefore 39 children aged 060 months were studied from each slum. During door-todoor survey, mother of study subjects were briefed about the study and their consent was obtained for the same. If 
there was more than one sibling in a house, then the youngest sibling was chosen for the study.

\section{Methodology}

A predesigned and pre-tested questionnaire was used to elicit the information from mother of study subjects. Information collected comprised the following major components-

Socio demographic variables- included age, sex, education and occupation of parents, religion, caste, socioeconomic status. Social class was assessed according to Modified Kuppuswamy socio economic classification. Detailed history of breast feeding practices was elicited.

Anthropometric examination- the height/ length, weight and Mid Upper Arm Circumference (MUAC) was recorded for each study subject. Every effort was made to get high order of accuracy in measurements.

Height: Height was measured for children who could stand. Height in centimeters was marked on a wall with the help of a measuring tape.

Length: This was measured with the help of infant meter for subjects who could not stand. The child was laid supine, with the head touching the vertical, rigid board.

Legs was fully extended by pressing over the knees, and feet was kept vertical at right angles.

Weight: The spring balance was suspended from the ceiling by the hook and the child was made to sit in the sling and weight recorded. For children who could stand, electronic weighing scale with an accuracy of 100 grams was used. The weighing scale was kept on a firm horizontal surface and the scale was zeroed before each session. The child was made to stand barefoot on the weighing machine with minimal clothing.

Protein Energy Malnutrition in the study subjects was assessed on the basis of: IAP classification, which is based on Weight for age and is suitable for Indian children

\section{Statistical Analysis}

Data was compiled and analysed using SPSS 23.0. Categorical variables were analysed using percentages and chi square test. Two tiles $\mathrm{p}$ value $<0.05$ was considered significant.

\section{Results}

As per IAP classification, 40.1\% subjects had normal weight for age while $59.9 \%$ were malnourished.There were $34.3 \%, 21.1 \%$ and $4.6 \%$ subjects with Grade I, II and III malnutrition. No study subject had Grade IV malnutrition. (Table 1)

The prevalence of malnutrition was maximum in the age group of 24-36 months (81.2\%) followed by $77.8 \%$ PEM subjects in the age group of 12-24 months.The association between nutritional status and age of study subjects was found to be statistically significant.There was no association of malnutrition with gender of the child and occupation of the mother. (Table 2)

Among children whose mothers were illiterate, $68.4 \%$ were malnourished as compared to $11.1 \%$ PEM subjects where mothers were educated upto intermediate. Significant association was found between nutritional status of children and their maternal education. PEM was also significantly associated with social class and place of delivery.

Prevalence of PEM was significantly higher $(85.4 \%)$ among study subjects who did not receive colostrum as compared to those who received it $(42.5 \%)$. Significant association was found between colostrum feeding and malnutrition. (Table 3) All the children whose mothers were not following the practice of breast feeding were malnourished. There was a significant association between PEM and practice of breast feeding. PEM was significantly associated with timing of initiation of breast feeding. Children whose mothers initiated breast feeding within 1 hour had lower prevalence of PEM (20.4\%) as compared to those who initiated after 1 hour $(63.0 \%)$. There was no association between practice of giving pre-lacteal feed and PEM.

Upon multiple logistic regression analysis, age $(\mathrm{OR}=0.438)$, timing initiation of breast feeding $(\mathrm{OR}=0.682)$, colostrum feeding $(\mathrm{OR}=0.364)$, practice of breast feeding $(\mathrm{OR}=3.611)$ and initiation of complementary feeding at $>6$ months $(\mathrm{OR}=2.651)$ were significantly associated with PEM. (Table 4)

Table 1: Nutritional status of study subjects

\begin{tabular}{|l|c|c|}
\hline \multirow{2}{*}{ Nutritional status } & \multicolumn{2}{|c|}{ Study subjects } \\
\cline { 2 - 3 } & No. & \% \\
\hline Normal & 158 & 40.1 \\
\hline Grade I & 135 & 34.3 \\
\hline Grade II & 83 & 21.1 \\
\hline Grade III & 18 & 4.6 \\
\hline Grade IV & - & - \\
\hline Total & 394 & 100 \\
\hline
\end{tabular}


Table 2: Determinants of PEM in study subjects

\begin{tabular}{|c|c|c|c|c|}
\hline \multirow{2}{*}{$\begin{array}{l}\text { Determinants } \\
\text { Age in months }\end{array}$} & \multirow{2}{*}{$\begin{array}{c}\text { Total } \\
\text { No. }(n=394)\end{array}$} & \multicolumn{2}{|c|}{ PEM } & \multirow[t]{2}{*}{ P value } \\
\hline & & No.(n=236) & $\%$ & \\
\hline $0-12$ & 54 & 26 & 48.1 & \multirow[t]{5}{*}{$<0.05$} \\
\hline $12-24$ & 63 & 49 & 77.8 & \\
\hline $24-36$ & 85 & 69 & 81.2 & \\
\hline $36-48$ & 110 & 57 & 51.8 & \\
\hline $48-60$ & 82 & 35 & 42.7 & \\
\hline \multicolumn{5}{|l|}{ Gender } \\
\hline Male & 261 & 161 & 61.7 & \multirow{2}{*}{$>0.05$} \\
\hline Female & 133 & 75 & 56.4 & \\
\hline \multicolumn{5}{|l|}{ Education of mother } \\
\hline Illiterate & 174 & 119 & 68.4 & \multirow[t]{7}{*}{$<0.05$} \\
\hline Primary & 149 & 83 & 55.7 & \\
\hline Middle & 48 & 28 & 58.3 & \\
\hline High school & 11 & 5 & 45.5 & \\
\hline Intermediate and above & 9 & 1 & 11.1 & \\
\hline Graduate/ post graduate & 3 & 0 & 0.0 & \\
\hline Professional degree & - & - & - & \\
\hline \multicolumn{5}{|l|}{ Occupation of mother } \\
\hline Unemployed & 299 & 178 & 59.5 & \multirow[t]{2}{*}{$>0.05$} \\
\hline Employed & 95 & 58 & 61.1 & \\
\hline \multicolumn{5}{|l|}{ Social class } \\
\hline I & 2 & - & - & \multirow[t]{5}{*}{$<0.05$} \\
\hline II & 17 & 2 & 11.8 & \\
\hline III & 48 & 31 & 64.6 & \\
\hline IV & 285 & 168 & 58.9 & \\
\hline $\mathrm{V}$ & 42 & 35 & 83.3 & \\
\hline \multicolumn{5}{|l|}{ Place of delivery } \\
\hline Home & 312 & 207 & 66.3 & \multirow{2}{*}{$<0.05$} \\
\hline Institutional & 82 & 29 & 35.4 & \\
\hline
\end{tabular}

Table 3: Determinants of PEM in study subjects

\begin{tabular}{|c|c|c|c|c|}
\hline Determinants & Total & \multicolumn{2}{|c|}{ PEM } & $\mathrm{P}$ value \\
\hline \multicolumn{5}{|c|}{ Time of initiation of breast feeding* } \\
\hline$<1 \mathrm{hr}$ & 279 & 57 & 20.4 & \multirow{2}{*}{$<0.05$} \\
\hline$>1 \mathrm{hr}$ & 92 & 58 & 63.0 & \\
\hline \multicolumn{5}{|c|}{ Practice of breast feeding } \\
\hline Yes & 371 & 213 & 57.4 & \multirow[t]{2}{*}{$<0.05$} \\
\hline No & 23 & 23 & 100.0 & \\
\hline \multicolumn{5}{|l|}{ Colostrum given* } \\
\hline Yes & 254 & 108 & 42.5 & \multirow{2}{*}{$<0.05$} \\
\hline No & 117 & 100 & 85.4 & \\
\hline \multicolumn{5}{|l|}{ Pre-lacteal feed } \\
\hline Yes & 152 & 88 & 57.9 & \multirow[t]{2}{*}{$>0.05$} \\
\hline No & 230 & 120 & 52.2 & \\
\hline \multicolumn{5}{|c|}{ Initiation of complementary feeding } \\
\hline At 6 months & 320 & 211 & 65.9 & \multirow[t]{2}{*}{$<0.05$} \\
\hline$<6$ months & 74 & 25 & 33.8 & \\
\hline
\end{tabular}

*371 mothers were practising breast feeding 
Table 4: Multiple logistic regression analysis of determinants of PEM

\begin{tabular}{|l|c|c|c|c|}
\hline \multicolumn{1}{|c|}{ Determinant } & Odds ratio & Lower limit & Upper limit & P value \\
\hline Age(Ref=0-12 months) & 0.438 & 0.153 & 0.786 & $0.006^{*}$ \\
\hline $\begin{array}{l}\text { Social class(Ref=Social } \\
\text { class 1) }\end{array}$ & 2.715 & 0.645 & 3.651 & 0.654 \\
\hline $\begin{array}{l}\text { Timing of initiation of } \\
\text { (Ref=>1hr) }\end{array}$ & 0.682 & 0.351 & .865 & $0.005^{*}$ \\
\hline $\begin{array}{l}\text { Colostrum given (Ref = } \\
\text { No) }\end{array}$ & 0.364 & 0.151 & 0.805 & $0.037^{*}$ \\
\hline $\begin{array}{l}\text { Practice of breast feeding } \\
\text { Ref=Yes) }\end{array}$ & 3.611 & 2.543 & 6.314 & $<0.001^{*}$ \\
\hline $\begin{array}{l}\text { Time of initiation of } \\
\text { complementary feeding } \\
\text { (Ref= At 6months) }\end{array}$ & 2.651 & 1.461 & 5.158 & $<0.001^{*}$ \\
\hline
\end{tabular}

\section{Discussion}

In our study, 59.1\% subjects had PEM, which is almost similar to the findings (46.06\%) of Mittal A et al in a study from Patiala and of Chaturvedi Manish et al from Agra who reported a prevalence of PEM of 53.2\% among children. ${ }^{5,6}$

Protein Energy Malnutrition has a multifactorial causation, which includes social and behavioural factors, customs and beliefs, dietary and environmental factors, which in turn are affected by poverty and illiteracy. The growth and nutritional outcome of children is dependent on a complex relationship between the intrinsic characteristics of the child and the competence of mother in providing child care. The reason for malnutrition being more prevalent among lower socioeconomic groups may be due to unavailability of food, insufficient purchasing power, inappropriate distribution and inadequate utilization which might make the children vulnerable to malnutrition in a deprived community.

In the present study, the prevalence of PEM was highest $(81.2 \%)$ in the age group of 24-36 months followed by $77.8 \%$ subjects in the age group of $12-24$ months. Our findings are similar to those of Narkhede Vinod et al with maximum PEM in 13-24 months. ${ }^{7}$ A study by Srivastava Anurag et al from Bareilly also supports our result. ${ }^{8}$ In this study, as per IAP classification, no significant association was seen between sex of the child and nutritional status, though percentage of malnutrition was more in male children $(61.7 \%)$ as compared to female children $(56.4 \%)$. Similarly, no significant association was found by Narkhede Vinod et al in Nagpur. ${ }^{8}$

In our study, among the children of illiterate mothers, $68.4 \%$ subjects had PEM. No malnourished child was reported among subjects whose mothers were educated upto graduation or above. This may be because of practice of favorable practice and behaviors among educated mothers with regard to child health and nutrition which ultimately affect the nutritional status of children. Findings of Mittal A et al and Ahmad Ehtisham et al also supported our result. ${ }^{9}$

In the present study, the assessment of socioeconomic status was done on the basis of Modified Kuppuswamy classification. It was observed that majority of the subjects (83.3\%) of social class V had PEM. Among subjects of class II, only $11.8 \%$ were malnourished. This distribution of
PEM across socioeconomic strata in our study was found to be statistically significant. Prasot Ram Milan et al also reported significant association between the two. ${ }^{10}$

Our study revealed that among subjects who received colostrum, only $42.5 \%$ had PEM against those who were not given colostrum $(85.4 \%)$. Colostrum feeding was thus found to be protective against PEM. Baranwal Kavita et al also reported similar findings in Varanasi, with only $43.2 \%$ malnutrition among subjects who were fed colostrum. ${ }^{11}$

In the present study, it was observed that children of mothers who started complementary feeding at the age of 6 months had lower prevalence of PEM. Similar trend was also seen by K Madhu et al and Bhanderi Dinesh et al.

In the present study, multiple logistic regression analysis revealed age, timing of initiation of breast feeding, colostrum feeding, practice of breast feeding and timing of initiation of complementary feeding at 6 months were significantly associated with PEM.

In conclusion, this study reveals that correction of simple breast feeding practices can help to go a long way in bringing down the prevalence of PEM among under five children in India.

\section{Conflict of Interest: Nil}

\section{References}

1. UNICEF. The situation of children in India, A Profile. Available from:

2011.http/www.unicef.org/sitan/files/SitAn_India_May_2011. pdf

2. NFHS-3 (National Family Health Survey-3), Ministry of Health and Family Welfare, 2005-2006. Available from: http/pdf.usaid.gov/pdf_docs/PNADK385.pdf.

3. Rai Manjusha, Rai Arundhati, Pandey Sudha: Study of weaning practices of infants in selected rural and urban communities of Azamgarh district. Indian J Prev Soc Med. 2007;38(3,4):132-134.

4. UNICEF. The State of the World's Children 2014 in numbers. Available from:

http/www.unicef.org/publications/files/SOWC2014_In_Numb ers_28_Jan.pdf

5. A Mittal, J Singh, SK Ahluwalia. Effect of maternal factors on nutritional status of 1-5-year-old children in urban slum population. IJCM. 22007;32(4):264-267 
6. Manish Chaturvedi, D Nandan, SC Gupta. Rapid assessment of nutritional status of children in agra district. Indian J Prev Soc Med. 2006;37(3\& 4).

7. Narkhede Vinod, Likhar Swarnakanta, Pitale Smita, Durge Pushpa. Nutritional status and dietary pattern of under five children in urban slum area. Natl J Community Med. 2011;2(1):143-148.

8. Srivastava Anurag, Bhushan Kumar, Mahmood Syed Esam, Shrotriya Ved Prakash, Mishra Srivastava Payal, ShaifaliIram. Nutritional status of under five children in urban slums of Bareilly. Indian J Matern Child Health. 2012;14(1):1-8.

9. Ahmad Ehtisham, Khalil Salman, Khan Zulfia: Nutritional status in children (1-5 yrs) - a rural study. Indian J Community Health. 2011;23(2):84-86.

10. Ram Milan Prasot, Sudhir Kumar Verma, Saurabh Kashyap, Mukesh Kr. Kanaujiya. An epidemiological study of Protein Energy Malnutrition (PEM) among 1-6 years children in rural Lucknow, Uttar Pradesh, India. J Dent Med Sci.

2014;13(3):10-14.
11. Baranwal Kavita, Gupta VM, Mishra RN. Profile of morbidity $\&$ their effect on nutritional status of underfive children, in urban slum community. Indian J Prev Soc Med. 2011;42(2):123-126.

How to cite this article: Midha T, Nigam S, Martolia DS, Kaur Samarjeet. Prevalence and determinants of protein energy malnutrition among under five children in slums of Kannauj district. Indian $\mathbf{J}$ Forensic Community Med. 2018;5(4):218-222. 